$11-4-2017$

\title{
A comparison of perceptions of barriers to academic success among high-ability students from high- and low-income groups: Exposing poverty of a different kind
}

\author{
Jennifer Riedl Cross \\ College of William and Mary, jrcross@wm.edu \\ Andrea Dawn Frazier \\ Mihyeon Kim \\ College of William and Mary \\ Tracy L. Cross \\ College of William and Mary, tlcross@wm.edu
}

Follow this and additional works at: https://scholarworks.wm.edu/educationpubs

Part of the Gifted Education Commons

\section{Recommended Citation}

Cross, Jennifer Riedl; Frazier, Andrea Dawn; Kim, Mihyeon; and Cross, Tracy L., A comparison of perceptions of barriers to academic success among high-ability students from high- and low-income groups: Exposing poverty of a different kind (2017). Gifted Child Quarterly, 62(1), 111-129. https://doi.org/10.1177/0016986217738050 
RUNNING HEAD: HIGH AND LOW INCOME BARRIERS

A Comparison of Perceptions of Barriers to Academic Success Among High-Ability Students from High- and Low-Income Groups: Exposing Poverty of a Different Kind

\author{
Jennifer Riedl Cross, Ph.D. \\ William \& Mary \\ Andrea D. Frazier, Ph.D. \\ Columbus State University \\ Mihyeon Kim, Ph.D. \\ William \& Mary \\ Tracy L. Cross \\ William \& Mary
}

Final version accepted for publication

Cross, J. R., Frazier, A. D., Kim, M., \& Cross, T. L. (2018). A comparison of perceptions of barriers to academic success among high-ability students from high- and low-income groups: Exposing poverty of a different kind. Gifted Child Quarterly, 62, 111129.https://doi.org/10.1177/0016986217738050 


\begin{abstract}
In 14 focus group interviews, $6^{\text {th }}-8^{\text {th }}$ grade high-ability students from high- $(n=36)$ and low-income $(n=45)$ families were asked to describe the barriers they perceived to their academic success. Three themes were identified through the qualitative analysis: Constraining Environments, Integration versus Isolation, and Resource Plenty versus Resource Poor. Students in both groups experienced environments not conducive to learning, inhibiting peers, and teachers as a barrier. Students in the low-income group described mayhem in their schools, which interfered significantly with learning. These students were highly integrated in their school community, whereas the students in the high-income group were socially isolated from both peers and teachers. Both groups exhibited issues of poor fit within their schools: autonomy and competence for both, relatedness for students in the high-income group. Attention to these issues will help to support these students in achieving their potential.
\end{abstract}




\section{A Comparison of Perceptions of Barriers to Academic Success Among High-Ability Students from High- and Low-Income Groups: Exposing Poverty of a Different Kind}

Students with the potential for high academic achievement exist at all income levels, yet the success rates of students from low-income backgrounds are consistently lower than their higher income counterparts (Reardon, 2011). Although dropout rates have decreased by half among students from low-income families over the past three decades, in 2009, they were five times more likely to drop out of high school than their high-income peers (7.4\% vs. 1.4\%; Chapman, Laird, Ifill, \& KewalRamani, 2011). These statistics are a source of concern for the gifted education community, as there is evidence that students with gifts and talents are among those from low-income families who are not achieving to their potential or even dropping out (e.g., Renzulli \& Park, 2000; Zabloski \& Milacci, 2012). The research base exploring the experience of low-income, high-ability youth is nascent, thus, this qualitative study sought to contribute to the knowledge base by asking high-ability students from low-income backgrounds to describe their perceptions of barriers to their academic achievement. By asking the same questions of high-ability students from high-income backgrounds, we were able to compare and contrast the two.

Reports of the achievement gap between low- and high-income students in the US (Burney \& Beilke, 2008; Reardon, 2011) and of underrepresentation of low-income students in gifted and advanced academic programs (e.g., Whiting \& Ford, 2009) stimulated the research question driving this study: Are there differences in the barriers perceived by high ability students from high- and low-income backgrounds? Sparse research has examined associated perceptions. In a comparison of advantaged and disadvantaged gifted $7^{\text {th }}$ and $8^{\text {th }}$ grade students, VanTassel-Baska, Olszewski-Kubilius and Kulieke (1994) found the low-income students had 
significantly poorer self-perceptions of academic competence and social support. The African American gifted students in their sample tended to have higher self-esteem and more confidence in their social competence, however. Low-income African American gifted students in VanTassel-Baska, Feng, Swanson, Quek and Chandler's (2009) qualitative study were not socially integrated in their gifted classes. They were perceived as loners by teachers and expressed a desire to maintain friendships outside their gifted classes. The need to expand this small research base is critical. At present, the bulk of research on low-income, high-ability students concerns their identification and inclusion in gifted programming, not the psychosocial aspects relevant to their persistence in them. Using a basic interpretive qualitative study design (Kahlke, 2014; Merriam \& Tisdell, 2015; Percy, Kostere, \& Kostere, 2015), our purpose was to understand the phenomenon of barriers to achievement as the students described it, in the hope of better understanding the differences between the two groups.

Eccles's (2004) stage-environment fit theory and Ryan and Deci’s (2002) selfdetermination theory were used to locate the students' discussion of barriers within a theoretical framework in the analysis of the interviews. These theories are supported by substantial evidence and provide plausible explanations for the locus of barriers. Children are differentially impacted by social environments due to the developmental stage of the child and any transitions the child may be experiencing. Schools, as well as families, are social environments that surround children and make a direct contribution to their effective functioning, in large part because these environments respond to individual characteristics children bring to the environment, with varying degrees of success (Eccles et al., 1993). For example, Alfeld-Liro, Fredricks, Hruda, Patrick, Ryan and Eccles (1998) found that the middle- to upper-middle class parents of the talented adolescents in their study provided a fit for their overall development, including talent 
development, through structured autonomy in decision making, provision of opportunities and resources, consistent encouragement and support, belief in the benefits of involvement, and realistic expectations.

Eccles and Roeser (1999) used Bronfenbrenner's (1979) ecological model as a basis for explaining how schools impact student development. Schools are multilevel as well as hierarchical and contextualized as systems that encompass the classroom; interactions between the teacher, peers in the class and the students (including class activities and instructional approaches); the school and its impact on teachers; and school board and other actors who influence the climate in individual schools (neighborhood, legislators, etc.; Eccles \& Roeser, 1999). A school's impact on the child is determined by how well the developmental appropriateness of the complex academic milieu matches the needs of the child - his or her fit with the environment (Eccles \& Midgley, 1989).

According to Ryan and Deci's (2002) self-determination theory, all people have needs for autonomy (to perceive that one is the source of his or her own behavior), competence (to be effective in one's environment), and relatedness (to interact with, care for, and be connected to others). An appropriate fit for middle-school students would be found in an environment that allows students a degree of autonomy, with the ability to make choices and to engage in work they find relevant (Wang \& Eccles, 2013); that allows a means of developing their competence, with accessible evidence of their success; and that is within an atmosphere of relatedness, where students feel connected to adults in the school and to one another.

Organizational climate and schoolwide practices and policies affect fit at the school level. The availability of extracurriculars, relationships among teachers and administrators, and overall school environment are all examples of elements of school-level functioning that could impact 
student fit (Eccles \& Roeser, 2009). At the classroom level, fit is affected by "teacher beliefs and instructional practices, teacher-student relationships, the nature and design of tasks and instruction, and the nature and structure of classroom activities and groups" (Eccles \& Roeser, 2009 , p. 405). Studies with high-achieving students have demonstrated that an autonomy supportive environment enhanced students' academic motivation (Garn, Matthews, \& Jolly, 2010; Griffin, 2006; Wang, 2012). In a study of gifted high school students, Hoekman, McCormick, and Gross (1999) identified a negative relationship between boredom and intrinsic motivation, suggesting the need for a positive academic fit. Classmates can support peers' autonomy by allowing or enhancing their freedom to pursue goals, but they can negatively affect a student's autonomy when their behavior inhibits the student's choice-making possibilities or goal pursuit.

A belief in one's competence is critical to motivation (Deci \& Ryan, 2000) and is both antecedent to and an outcome of academic success (Schunk \& Pajares, 2005). Students will develop confidence in their abilities when given opportunities to be successful with increasingly challenging tasks. Peers' self-efficacy beliefs are infectious and the modeling of classmates can increase or decrease students' beliefs in their own competence (Bandura, 1997). Teachers promote competence beliefs when they are confident in their teaching abilities (Schunk \& Pajares, 2005) and when activities are structured to clearly communicate expectations, guidance, and feedback (Reeve, 2006). Among high-ability students, competence perceptions can only be accurate when they have had opportunities to work at a sufficiently high level.

To support students in achieving to their maximum potential, an understanding of their perceived and actual barriers is necessary. In this study, we examine the words of these highpotential students to learn more about their fit in academic environments, that we may contribute 
to an eventual solution to the gap in achievement between students from high- and low-income backgrounds.

\section{Method}

A series of focus group interviews provided data for this basic interpretive qualitative research study. A basic interpretive qualitative design, also known as generic qualitative design (Merriam \& Tisdell, 2015), is appropriate when the research question is aimed at experiences of participants rather than the essence of a phenomena, cultural exploration, building theory, or honing in on a bounded system or multiple bounded systems (Percy et al., 2015). Basic interpretive qualitative research design rests on sample sizes in excess of 12 participants to better argue for data saturation and a clear explanation of methods used for data collection. In contrast to grounded theory or ethnography, basic interpretive qualitative research is not situated within a specific theoretical framework. Thus, researchers utilizing this approach must be transparent in showing how they came to understand their data (Cooper \& Endacott, 2007).

Focus groups can serve three methodological aims: 1) as a supplement to findings from an alternate source of data (e.g., survey research), 2) as a complement to other sources of data in a mixed methods study, and 3) as the sole source of data. The choice to use focus groups as the single data source is based on whether this design approach addresses the research purpose (Morgan, 1997). Cyr (2016) recommended focus group interviews as an appropriate method for exploring poorly understood phenomena. They can be an effective method for soliciting normative beliefs (Bloor, Frankland, Thomas, \& Robson, 2001), in this case, beliefs about barriers to achievement. Focus groups can also be an effective, child-friendly approach to interviewing, because they can lessen discomfort and positively undermine power differentials associated with being interviewed by an adult (Morgan et al, 2002; Punch, 2002). Data collection 
is often enriched when respondents are comfortable and when they begin telling stories to each other (Rodriguez, Schwartz, Lahman, \& Geist, 2011). Based on their analysis of health care interviews, Namey, Guest, McKenna and Chen (2016) reported the median number of focus group interviews required to reach thematic saturation was three to five.

\section{Participants}

To represent high-ability students in both high- and low-income populations, students in two enrichment programs sponsored by a university-based center for gifted studies were selected for participation in the study. One program was a two-week summer residential science, technology, engineering, and mathematics (STEM) camp for low-income, high-ability middle school students, offered free of charge through funding from a private foundation. Eligible students were rising $7^{\text {th }}$ graders from school districts with greater than $50 \%$ National School Lunch Program (NSLP) participants within a 75-mile radius of the university, who had family incomes of less than $\$ 45,000$ per year, and who were identified by their school district as having scored in the upper $10^{\text {th }}$ percentile on a nationally normed aptitude, creativity, or achievement test. Students who did not meet the $90^{\text {th }}$ percentile criteria, or for whom no test scores were available, were considered eligible via teacher, coordinator, or caregiver recommendation and evidence of performance. The inclusive criteria for this group was developed in consideration of the underrepresentation that often occurs in gifted programs using a traditional measurement or other methods that do not account for the dampening effects of these students' environment (Swanson, 2010). The low-income sample consisted of 45 students, $44 \%$ female; $84 \%$ African American, Hispanic, or Biracial; 16\% Caucasian. Two urban centers were within the region served by the program and a majority of students attended large, high-poverty schools. All students in the low-income enrichment program received parental permission to participate and 
were included in the study. Students in the low-income group will be referred to as Summer Camp (SC) students.

The high-income students ( $n=36 ; 56 \%$ female; $89 \%$ Caucasian; $11 \%$ African American, Asian, or Indian) were $6^{\text {th }}$ to $8^{\text {th }}$ graders participating in fee-based, half-day enrichment classes designed for gifted students - either on weekends through the school year or for one or two weeks in the summer. The enrichment program draws the majority of its students from within the same 75-mile radius of the university. To be eligible for the program, students scored in the $95^{\text {th }}$ percentile on any subscale of any standardized test. A large majority (74.2\%) of enrichment program families reported an average family income of more than $\$ 100,000$, and $43.6 \%$ of families reported annual incomes greater than $\$ 150,000$. Students in this group attended a variety of public and private schools, and several were home-schooled. All $6^{\text {th }}$ to $8^{\text {th }}$ grade students attending courses in the enrichment program were invited to participate and those who received parental permission were included in the study. Students in the high-income group will be referred to as Enrichment Program (EP) students.

\section{Procedure}

Two of the co-authors and one graduate assistant conducted 14 audiotaped interviews. The interviews were conducted in groups of 3-9, in most cases separated by gender at the suggestion of the Summer Camp participants, who claimed they could be "straight up" without the opposite gender present, a practice corroborated in prior research (e.g., Morgan, Gibbs, Maxwell, \& Britten, 2002). One interview included both genders for logistical reasons. The interviews began with a showing of a video of a 9-year-old boy, Caine, who had created an arcade from cardboard boxes (www.cainesarcade.com). At the conclusion of the video, the interviews began. These lasted between 30 and 45 minutes. After discussing Caine's goals and 
resources required, students were asked to consider academic goals and resources needed to achieve them. We then asked some form of the question "What things about you (characteristics) or your environment (resources) or people around you keep you from achieving your academic goals? Can you give us examples?" As discussions took various directions in regard to the different obstacles being described, follow-up questions were asked to keep students focused on the topic of barriers to their achievement.

The interviews with SC students were conducted first and were part of the curriculum for a class designed to address common obstacles to achievement for high ability students by boosting psychosocial awareness and skills. The interviews were the introduction to a fuller discussion over several class periods about goal setting and overcoming barriers to achievement and self-actualization and thus were designed to fit within a class period.

The enrichment program interviews occurred after the summer camp program had concluded. The students were drawn from a variety of enrichment program courses. Interviews were conducted during a lunch period and near the conclusion of the enrichment program, in classrooms similar to the setting of the summer camp interviews.

Semi-structured focus group interviews gave students' voices a priority (Creswell, 2013), while allowing students to explore their perceptions together. The interview protocol is included in the Appendix. The video and introductory questions were used to help the students feel comfortable answering questions in the form of an interview and to get the students talking with each other. We also established the framework for how the conversation would progress through these opening questions. The questions were also priming the students by asking them to examine key issues that we wanted to delve into later, but with the lens turned inward rather than outward. To that end, we asked them to begin examining goal setting, personal factors that help 
realize goals and environmental factors that help a person realize goals, using Caine as a model. The video and the introductory questions were used not only to build rapport, but also to ground the students in reality rather than hypothetical situations. The video was a concrete demonstration of goal setting and goal realization. This concreteness provided a real-world context for abstract ideas like environmental or personal barriers.

Multiple focus group interviews can strengthen consensus findings, particularly when the interviewees have break characteristics that could differentiate how a phenomenon is experienced (Knodel, 1993). In this case, the break characteristic was socioeconomic status. The use of multiple focus group interviews around our break characteristic captured one form of triangulation-triangulating data sources (Patton, 1999).

There is always the potential for a few vocal leaders to dominate a focus group interview (Morgan et al., 2002). We addressed this concern by striving to make the students comfortable, using small groups, and by calling on quieter participants. Multiple focus groups also ensure that no voice dominates. Likewise, the salience of interview themes for each group varied, allowing us to conclude we had captured a cross-section of concerns.

\section{Analysis}

Three of the co-authors completed inductive coding of the interviews, attending closely to the interactions among participants (Cyr, 2016). Dedoose, an online qualitative data analysis software package, was selected to facilitate analysis by the three co-authors independently, allowing for analyst triangulation (Patton, 1999). The researchers met multiple times online to come to agreement about the patterns identified. Most of these discussions were recorded using Google Hangout-On-Air. The conversations were lively exchanges wherein the co-authors 
debated individual interpretations of the data until consensus could be reached. These conversations served as digital memos and were vital to completing the write-up of results.

Data analysis in basic interpretive qualitative research can be inductive, guided by theory, or utilize the constant comparative method (Percy, et al., 2015). Analysis for this study was initially inductive and then transitioned to more theory-laden analysis influenced by stageenvironment fit theory and self-determination theory. In the first phase of analysis, the transcripts of the 14 interviews were read until "certain words, phrases, patterns of behavior, subjects' ways of thinking and events repeat" (Bogdan \& Biklen, 2007, p. 173). These repeated words, phrases, and ways of thinking led to our initial codes and were used to sort the data, separating similar data from other data (Maxwell, 2013). Once codes were obtained from this careful reading, coding was applied through Dedoose.

These codes and attached data were then reviewed to ascertain the implicit understanding of the coders and to derive definitions that would standardize the use of codes upon a second round of coding. The codes were also reviewed to determine any organizing principal to better apply codes in a consistent way and to determine a theoretical frame that situated what the data was beginning to say (Marshall \& Rossman, 2006; Maxwell, 2013). The students were implicitly speaking of academic contexts as places of barriers, ranging from within the individual to within the classroom to within the greater school community. Stage-environment fit theory (Eccles, 2004; Eccles \& Roeser, 1999) was used to further organize the codes at this point. The codes were fit under the categories indicated by the levels specified in the theory, with each category indicating a potential site of barriers. Eccles and Roeser (2009) articulated four levels of a school system that ranged from classrooms to "Schools as Embedded Organizations in the Larger Community” (p. 424). With one exception, our data aligned with two contexts - 
classrooms (Level 1) and school buildings (Level 2). For example, the initial code of "Peers as distractions" and its subcodes ("Peers take over class," "Peers distract individual," "Peers distract class," and "Peers as mayhem") was fit into the "Classrooms - Level 1" category.

Bronfenbrenner's (1979) ecological model, on which Eccles and Roeser's (1999) stageenvironment fit theory was based, includes individual and family characteristics at the center of human development. The importance of these characteristics to the analysis of barriers to achievement became evident during the coding process and it was necessary to include influences external to the school environment. This round of coding completed our "categorizing analysis" or analysis based on data similarity (Maxwell, 2013).

Maxwell (2013) argues that qualitative researchers might lose a true understanding of relationships embedded in the stories of interviewees by focusing exclusively on how data groups into categories. To overcome this limitation, one must not only identify how data are similar. An important step in analysis also includes understanding how data are contiguous. Thus, in the final stage of analysis, we worked to understand how our data was connected. It is in this final step that we began identifying potential themes. The self-determination theory components of competency, autonomy, and relatedness (Ryan \& Deci, 2002) were layered on top of our inductive codes and theoretical codes to "spotlight" (Maxwell, 2013) a coherent story, identifying linkages in the data that might have been missed otherwise (Maxwell, 2013). In particular, we wanted to know in what ways specific contexts in the student's schools (identified using stage-fit theory) met autonomy, competence and/or relatedness needs.

In approaching this area of analysis, we focused on the "Classroom" and "School Building" level codes. We believed that the barriers the students identified demonstrated a mismatch in meeting the needs of the students. Therefore, we sought to identify patterns in our 
coded material that indicated inability to address relatedness, competence, and autonomy needs. For example, how would "Teacher lacks control" material relate to autonomy, competence and relatedness? We concluded analysis when there was evidence of data saturation, as we saw overlap not only within the responses of our groups, but also across the two groups. Three themes were derived from this analysis.

\section{Findings}

Three primary themes emerged from the data: Constraining Environments; Integration versus Isolation; and Resource Plenty versus Resource Poor. Students from both high- and lowincome groups experienced threats to the fulfillment of their autonomy and competence needs. Social connections within the school community differed dramatically between the two groups, as did the resources available to students in both groups. Interview identifiers indicate group (high-income, Enrichment Program [EP], low-income, Summer Camp [SC]), gender (boys [B], girls [G], boys and girls [BG]), and interview number.

\section{Constraining Environments}

Students in both the high- and low-income groups describe challenges to their autonomy and competence, suggesting a poor fit with their environment. They describe frequent circumstances in which their ability to fulfill these needs are thwarted, although the most significant challenges have different sources in the two groups. It was clear that, in several ways, their school environments compromised their ability to act autonomously, to develop the level of competence they desire, and, for some, to have close personal relationships. See Table 1 for excerpts representative of this theme. 
Stagnant academic conditions. Students in both groups made it abundantly clear that there were many times in school when learning was not occurring. These stagnant academic conditions were perceived as barriers to their academic success. The strongest indicator of a poor fit in terms of autonomy and competence needs was students' frequent complaints of boredom. Students in both the SC and EP groups were often bored. Asked why his teachers let him sleep in class, one SC student said, "I'm too advanced. And most of the time there's nothing for me to do in math class. I finish everything” (SCB1, 7/25/12). Students from both groups describe being bored when lessons were not relevant, not paced well, or not adequately challenging. Among these high-ability students, being advanced in their schoolwork led to a lack of choices and, ultimately, boredom. Students in both groups were often left with nothing to do. The SC students reported sleeping in class, talking, and wandering the halls, while the EP students reported sitting and waiting. Both autonomy and competence needs were being thwarted when students were not actively engaged in learning.

The students complained of a lack of differentiated instruction, lack of variety in teaching strategies, and teacher stifling of organic engagement with content or with productive interaction with others (for SC students). SC students indicated that many students in their classes were bored, leading to misbehavior. EP students mentioned being in homogeneous or gifted classes, but these were not always satisfactory. Not having access to advanced classes was frustrating for some EP students (see Table 1), but SC students did not comment on their lack of advanced options. EP students frequently reported repetitive instruction and wasting time in review.

Inhibiting peers. Peers contributed to poor environmental fit by distracting students with their disruptive behavior. For example, students from both groups described peers talking or otherwise derailing class. As one EP student put it, "I think one of the biggest interruptions is the 
non-gifted kids who aren't as enthusiastic about learning and working hard to do your best. They're constantly causing interruptions and it's very hard to focus when they're in the back chatting with someone next to them" (EPG2, 7/17/13). An SC student described the same situation in his school: "Like, in class when the kids are talking and you can't really understand what the teacher is saying and then they give you homework on what they taught in class and you don't really know it because everybody was talking” (SCB1, 7/25/12). Many students, particularly those in the EP, were well aware of the effects of peers who are less serious about learning. These students distracted them or monopolized the teacher's attention. Among EP students, but not SC students, these behaviors among their fellow students led to negative feelings about and emotional distancing from their peers.

Peers can directly inhibit students' ability to fulfill their autonomy and competence needs. One SC girl described the pressure she received from peers to not achieve academically: “They're always like, man, you like a goody-two-shoes, man. You need to get low grades, you need a boyfriend, you need this and you need that. And I'm like nooo, I don't need that. But they keep pushing me and pushing me and I'm sick of that" (SCG1, 7/25/12). SC boys and girls were well aware of peer pressure to engage in negative activity. One girl described a friend pressuring her to check out the crack house on their way home from school. Bullying also inhibited the achievement of EP and SC boys and EP girls. Bullying was indicative of peer rejection and lack of support. It led some to believe they were being pressured to conform and were misunderstood. SC girls did not mention bullying as a barrier to their achievement.

Teachers contribute to poor fit. Teachers were frequently cited as a barrier to students' achievement. EP students were particularly harsh in their descriptions of teachers as lazy, negative, biased, gullible, and incompetent. SC students spoke more positively about their 
teachers, but a few described uncaring and biased teachers. Ineffective teachers, especially substitutes, could not control students' misbehavior, creating an atmosphere not conducive to learning.

Two EP girls described being ignored by the teacher when they raised their hands with the answer to a question. One SC boy described missing several homework assignments when he transitioned into an honors class, because he did not know where to look for the assignments. An EP girl worried about not learning when teachers gave unclear instructions. In one interview, several EP girls described their frustration when teachers rewarded disruptive or less focused peers with attention, assistance, or extra time. They felt it diminished their own efforts. One EP girl stopped performing when teachers publicly read out students' grades: "I was kind of happy [with her $\mathrm{A}+$ ], but I don't like it whenever teachers do that because it kind of makes me more of a target for kids to pick on me and call me names" (EPG2, 7/17/13). Although they were competent students, they were aware that their exceptional ability was not in every area. As one EP student put it, "We're not so amazing. We still need help.” (EPB1, 3/9/13). SC and EP students expressed frustration with their inability to work at the pace they prefer, often having to repeat material or wait for peers to catch up (see Table 1).

Mayhem in students' environment. With few exceptions, the most severe poor fit was at the school-level and affected only SC students. All SC students attended schools in lowincome districts (> 50\% NSLP). The atmosphere described in some of the schools was characterized by surveillance and a lack of trust. Discipline was maintained harshly, with security guards a dominant feature in many of the low-income schools. Fighting was commonplace, with students claiming to have as many as 10 or 20 fights in a year and five in one day at one school. One student described walking unknowingly into a fight, and another worried 
that he could not predict what might happen when they occurred near him. In contrast, fights may have happened at the schools of the EP students, but they were generally not very upsetting (see Table 1).

Dramatic misbehavior in some low-income schools included trashcans being set on fire and thrown down the stairwell, students throwing rocks, and students attempting to jump from the roof. Students recounted peers running through the halls, hiding from the security guards to roam the halls, and smoking in the bathrooms. One of the SC interviews included several shocking examples of havoc in school including bomb threats, peers bringing guns to school, drug dealing or use in school, K9 squad locker searches, and peers being questioned by police at school as witnesses to a crime. Some students were required to eat lunch in their classrooms rather than the cafeteria in response to fighting, and an entire grade level had separate start and end times to avoid violent interaction with peers. These incidents made some students feel that school was "unsafe, ghetto, bad" (SCBG4, 7/25/12). One girl expressed her feelings this way: "It's a bad school with a bunch of bad people" (SCBG4, 7/25/12).

A tumultuous academic environment could be generated by a host of school actors ranging from teachers to peers to security guards. Disruptive peers in the hallways, in particular, but also in the classroom, introduced an element of turmoil to the academic environment. Teachers would also be caught up in any chaos in the hallways, suspending class as they attended to students involved in negative behavior. Flummoxed teachers and agitated students would then struggle to return to the business of learning, once the uproar in the hallways had been addressed.

Security guards inhabited complex roles in some of the low-income schools, introducing elements of intimidation and unpredictability (see Table 1). Some acted as educators, but, for the 
most part, they were there to maintain order. In some situations, they contributed to students' feelings of safety, but in others they were adversarial or threatening. EP students rarely mentioned security guards. Security guards may or may not have been present, were often unarmed when present, and were generally ignored. One EP student claimed to need them at his school, "Because usually there's like this hobo dude who walks across the parking lot and it's really, really creepy." (EPB2, 7/18/13). In stark contrast with SC students, whose experience with security guards was to be dominated by them or to be protected from their peers by them, EP students would like to have had security from outside disruption (i.e, "creepy" strangers).

The disorder in some low-income schools created a negative environment and poor fit for learners of all ability levels. Peer mayhem and peer boredom were not generalized or theoretical, but rich and impactful. As one young man put it, "It just makes [me] feel like I'm always near the fights for some reason" (SCB1, 7/25/12). Fighting and over-the-top raucous behavior was debilitating, as teachers left the classroom to break up fights or to assist in drug searches or school lockdowns, reducing engaged time for learning (see Table 1). When peers were out of control, an issue of both peer and teacher effects, the students had difficulty learning.

\section{Integration versus Isolation}

The theme of Integration versus Isolation emerged from a recognition of the degree to which relatedness, or a feeling of belonging, facilitated fit within classrooms and schools. This theme was evident in the markedly different experiences the two groups described of their social relationships. EP students showed signs of isolation, while SC students appeared to be entrenched in their social environments - participants in the goings-on in their school communities and engaged in supportive relationships (see Table 2). SC students had problems with teachers, but many supportive teachers, as well. They readily identified supportive 
relationships with teachers, some noting that teachers publicly "brag" about them to other students and to their parents. The SC students wanted teachers to care for them and respect them. In one example of a student's positive relationship with teachers, this student explained what he would do in a boring class:

Student: $\quad$ You ask her to step it up a notch and do something that's very active and helps us also learn at the same time.

Interviewer: So you try to do it or the teacher tries to do it?

Student: Y'all both got to do it. You tell her some of your ideas and then you can put them in your activity or something. (SCB1, 7/25/12)

SC students also identified other school personnel with whom they felt they had positive relationships, and students were often positively and publicly recognized for their achievements by school administrators.

\section{INSERT TABLE 2 ABOUT HERE}

Several SC students indicated their friends were also good students. For example, one friend was in the gifted program and a second could have also attended the SC, but decided against it. Peers also served as a motivator to do well. When asked who she talks with to stay academically focused, one student responded, “This girl named Darlene ${ }^{1}$, she's like really excited but really smart. She keeps you 'Woooo!' and she, like, does it in a smart type of way so it keeps you educated" (SCG3, 7/25/12). However, some of their friends had migrated into the "wrong crowd." Some students noted being on guard against socializing with the "wrong crowd," a group likely involved in drug use, stealing, or other negative behavior. A second category of the "wrong crowd" was unengaged in academics - "working on [their] social life too

\footnotetext{
${ }^{1}$ pseudonym
} 
much" (SCB1, 7/25/12). Students who witnessed a transformation of a friend into a person who had given up on school considered this lost potential a waste.

SC students were more likely to talk of their peers as offering up attractive distraction-socializing too much was considered worrisome and sometimes resulted in disciplinary action. Some peer-related circumstances in which students in the low-income group found themselves drew them away from academics, even when they wanted to focus on schoolwork. For example, one girl was frustrated after going to a friend's house to work on homework, but then was waylaid by her friend's other plans. One boy felt insulted when he was questioned by authorities after having been in the locker room where other students had engaged in drug-related activity. They were also apt to wonder or worry about the long-term impact of this pressure. As one young lady lamented, "Friends that try to pressure you into stuff and it makes you forget all about what your achievement is. Then it just slips away" (SCG2, 7/25/12).

EP students also reported pressure to deviate from an academic focus, but did not indicate a worry that they socialized too much with their peers. In fact, they seemed to stand alongside the milieu of their classes, rather than be a part of it. EP students were more apt to report a lack of support from peers, which was further compounded by rejection, bullying, and isolation (see Table 2).

EP students recounted emotion-laden experiences with a specific person or group of people. In one interview, girls were bothered by the seeming power of a few manipulative and controlling individuals to drive the environment in class. One of the students felt compelled to reject this influence:

They even have some of the teachers like wrapped around their fingers, like at my school, there's this main girl, like she has everybody in that school...like she can walk up to one 
of the 10th grade guys and say, "Go get my book" and they'll go get her book! And I'm one of the only people who will not get her book, I'm like, "You have 2 legs! Get your book! I'm not gonna serve you" and also for some teachers, if we're playing - sometimes the teachers give us games, which, like, kind of waste time. If she's on one team, we will be looking up something and we'll have like 30 seconds to find it. She'll on her team be like, "Please, can I have some more time?" and they'll give her 10 minutes, and they'll give us 30 seconds, so the other team will always lose if she's not there. (EPG1, 3/16/13) It is evident in this excerpt that teachers were considered enablers of poor behavior by their peers, and the students were less likely to indicate they experienced teacher support. In fact, not a single EP student expressed a positive opinion of their teachers.

EP students reported often feeling alienated by peers who did not share their work ethic, as evidenced by assumptions that they intimidated other students or in disparaging comments about other students' intelligence (see Table 2). They also either complained of others cheating off their work or were cynical about requests for help.

Student 1: If they weren't threatened by me they were always asking me to partner up with me or can you help me with this or ...

Student 2: Exactly. Like, I don't do well if someone's like, “Hey, my essay's on this and I need you to help me with it." If it's not a topic I'm passionate about, I very honestly cannot help you. To be honest I just feel like friends stay with me because I'm smart I can help them with their schoolwork and I'm like "Dude, what do you think I am? [A] computer? Do the work yourself." (EPG2, $7 / 17 / 13)$ 
EP girls, especially, indicated they were on the receiving end of both verbal and physical bullying (see Table 1).

Both SC and EP students experienced peer rejection, in large part because they believed their competence was not appreciated or valued by peers. Instead, doing well in school opened one up to name-calling, ridicule, and social isolation. However, isolation distinguished the academic experience for EP students. Several students felt isolation was part and parcel of being passionate about academics. Others seemed a little wounded. Commenting about her isolation, one girl claimed it "really hasn't worked on my self-esteem very well” (EPG2, 7/17/13). In this student's analysis, it is evident that her future orientation is a helpful coping strategy:

When there's that boundary line between a group of girls and somebody who's different from them, sure they might, like, consider you their friend, but when it comes to, like, social events they'd rather hang out with people that are very close to or very exact like them. When there is somebody that's different they don't exactly feel like they're safe around that person.... It doesn't really affect me much because A) I have more studying time. B) I know I'm the one that's going to succeed over them. If they're spending every Friday afternoon, every Saturday going to the movies whereas I have extra time to focus on what I'm passionate about, I'm most likely going to be the one who's getting advanced college degrees or succeeding where I have that passion and then them most likely not so much. (EPG2, 7/17/13)

Ownership of one's competence was clear among the EP students and was a factor in their relationships with peers. They resented other students attempting to cheat off their work or "freeload" when doing group work, although one student considered it his "job" to help struggling peers (EPB3, 7/9/14). 
Peers present a challenge to students in both groups when they try to take advantage of these high-ability students, co-opting or taking credit for their work. Among the EP students, less serious peers were rejected: “I can’t deal with immaturity. Biology is one of my favorite subjects, but if you're going to laugh and cause trouble every time the teacher says 'reproduction,' I can't deal with you" (EPG2, 7/17/13). Getting “stuck with" less able or serious peers inhibited learning, as in this example from a boy in the high-income group:

There's no [gifted] science at my school. And so you get stuck with a lot of idiots that just stop you from doing anything.... by disrupting the class doing other stupid things, messing stuff up so then none of us could do anything. (EPB2, 7/18/13)

Such criticisms were found among EP students, but rarely among their SC peers, who tended to be more sensitive to their peers and sometimes even enjoyed their misbehavior. When classmates of one EP boy began dancing on the table during class, he did not enjoy it: "I'm just there stuck — umm, ducking my head into my shirt and saying, 'What is wrong with my world?"' (EPB3, 7/9/14).

SC students who participated in this study were connected to the people in their school environments, at least as they were entering the seventh grade. They accepted and were accepted by peers, teachers, and other staff in the schools, with the possible exception of the security guards. In contrast, EP students spurned their peers or were rejected by them and had instrumental relationships with teachers, who often disappointed them by attending to classmates. SC students were integrated in their schools, whereas EP students were isolated.

\section{Resource Plenty versus Resource Poor}

To put the theme of resources into perspective, it must be noted that the emphasis in the interviews was on barriers to achievement, not supports. Inevitably, however, in all interviews, 
discussions of barriers included talk of the supports for students' success. In some cases, the resources brought to their achievement became obvious as students complained about their deficiencies. For example, frequent complaints about slow internet or peer problems in their "regular" classes made it clear that the EP students have computers with internet access and “non-regular" or advanced classes. Resources available to support achievement were conspicuously different between SC and EP students (see Table 3).

\section{INSERT TABLE 3 ABOUT HERE}

At the school level, resources were noticeably plenty among the EP students. For example, one student recognized the importance of the high-quality resources his school provided to his future plans.

I go to a private school also and I get a lot of opportunities I wouldn't get other places.

Like, in science we do different labs and, like, we use a lot of textbooks and microscopes that are really updated. ...It's a resource for me because we can get the new, fresh information that we can use when we are going into high school in the time when it really counts before you get into a college. (EPB1, 3/9/13)

However, not all the students had ready access to the resources they needed to pursue what they like. The school library policy limiting the number of books that can be checked out was frustrating to one EP boy, and slow internet access or computer startups frustrated the EP girls in one interview. This is in stark contrast to the SC student who wished for experiments in a science class or another who wished for more frequent access to a computer. Both groups of students were frustrated, but, where SC students may have had no access to the internet or limited access to computers even in school, EP students were disappointed in the speed of internet connections 
or the lack of advanced classes. One EP student identified her school's online management system as a key impediment to her success:

The biggest thing that interferes [with my learning] is definitely Edline.... Most of my teachers update it on a regular basis except...my English teacher says he updates it once a week, but it's more like maybe once a month. (EPG2, 7/17/13)

EP students wanted more and better versions of resources they already had while their SC peers would simply like access to those resources.

High achievement at the SC students' schools was rewarded with parties or opportunities to get out of class, as in the case of the Assistant Principal Award in one school, when they shadowed the assistant principal "and we don't have to do class" (SCBG4, 7/25/12). One SC student stated, "If you get passed advanced on your [state achievement exam], they give you a party. So I spent the week before the last week of school, I spent half of the week outside playing because I got passed advanced on all of them" (SCG1, 7/25/12). Their EP peers were simultaneously being rewarded with entry in competitions and opportunities for enrichment or advanced programs. One EP student explains, "Because of my school and my high SAT level, I'm recommended for extracurricular things, like, pretty soon I'll be doing several classes at Johns Hopkins, Center for Talented Youth, and I'm in multiple online competitions" (EPB1, $3 / 9 / 13)$.

Individual-Level Resources. One component of the Resources theme did not conform to the classroom and school building contexts of Eccles and Roeser's (2009) environmental model, but it clearly contributed to students' academic fit and was, therefore, included in this theme. As students described barriers to their academic success, the resources they brought as individuals were frequently mentioned by both EP and SC students. Their personal characteristics, including 
features of their lives outside of school, affected fit within it (Bronfenbrenner, 1979; McNair \& Johnson, 2009). Students in the EP and SC groups saw themselves as a resource. Students in both groups showed strong competence beliefs and recognized the role of their own efforts and characteristics in the development of competence. Effort was seen as a necessary component to success and persistence as a contributing characteristic. Caring to develop their competence was also viewed as a key factor, as this EP girl describes: "I care a lot about my academics - like a lot. Like, I don't want to fail in school" (EPG4, 7/10/14). Several of the EP students described taking their learning into their own hands, working ahead of peers to continue developing their competence.

Family members were the most prominent resource for both groups of students, with parents the major motivators and supports for their success. Siblings, both older to provide a role model and younger for whom to be a role model, were also a resource for students in the highand low-income groups. Extended family - cousins, grandparents, uncles, aunts - also served as a resource for students in both groups. Among the SC, but not EP students, coaches, teachers, and principals were named as resources in achieving their academic goals.

Parents valued their children's education, as evidenced by comments from students in both groups about their pressure to achieve. Parents of students in both groups contacted teachers or administrators when they were concerned their children were not learning. Parents of EP students were willing to pay tuition for enrichment programs and to transport their children, sometimes great distances - an impossibility for the low-income students. One EP student was participating in the classes while his family was visiting on vacation from a state nearly 1,000 miles away and another travelled weekly from a state nearly 400 miles away. Several students participating in the fee-based EP were regularly driven more than an hour each way. 
Although they may not have been able to afford expensive out-of-school educational options, parents of SC students showed their support for academics by persuading their children to leave home for the two-week residential camp or by being amenable to their children's requests to go. Although there was no financial expense for the summer camp, this type of parental engagement showcases how much they valued their children's education. Parents not only encouraged their children's involvement in this type of academic experience, but were also willing to send them to be cared for by strangers for two weeks. For those parents without personal transportation, such an arrangement is an especial show of trust.

Among EP students, family members were frequently named as resources when schoolwork was difficult. Parents sometimes intervened when students were struggling or needed special accommodations. Family members also exposed them to educational experiences, including, but not limited to, the enrichment program they were attending at the time of the interviews. As with the SC students, EP students wanted to do well for their parents, "out of love" (EPB3, 7/9/14). Some SC students had family members who had had negative experiences in school, but they also had parents who expressed a desire for them to be successful in school to ensure a brighter future.

Many students were encouraged by family members to pursue their interests, but some of the SC students sometimes faced exceptional barriers in this regard. For example, the grandmother of one SC girl refused to support her career aspiration (becoming a chef), pushing her to become a preacher. One girl described how her family responsibilities sometimes overwhelmed academic pursuits. While her single mother worked full-time as an on-call nurse, this student cooked, cleaned, and cared for a younger sibling, leaving little time for homework. At the same age, her EP peers were participating in advanced enrichment classes and preparing 
for their future careers modeled on the academic or professional examples of family members. Families also provided environmental resources for additional development. EP students, but not those in the SC, described the computers they used for building video games and travel to classes, historic sites, and other enrichment opportunities.

Both groups of students had some resources in plenty. SC students experienced a wealth of resources in themselves and in their relationships with supportive family and community. In addition to their personal characteristics as a resource, EP students had connected, in-the-know family members and opportunities both in and out of school for advancing their academic achievement (see Table 3). Table 4 presents a comparison of these and other findings for the two groups.

\section{INSERT TABLE 4 ABOUT HERE}

\section{Discussion}

Statistics comparing high- and low-income student achievement have alerted the public to a crisis of inequality, even among the nation's most capable students (e.g., Reardon, 2011). In this study, we attempted to reveal differences in the obstacles to achievement experienced by high-ability students from different socioeconomic strata. Examining the interviews through the lens of self-determination theory, we found poor fit between both groups of students and their environments. The three themes of Constraining Environments, Integration versus Isolation, and Resource Plenty versus Resource Poor capture important aspects of these students' experience. To keep students in both groups on a positive trajectory at the level of which they are capable, ameliorative action should be taken. We discuss the implications of our findings and offer suggestions for educators.

\section{Strengths and Problem Areas}


Students in the high-income, EP group described numerous strengths, including many environmental resources, from technology to advanced educational opportunities. School and family environments often interact to influence children's achievement (McNair \& Johnson, 2009). Thus, it should not come as a surprise to find that EP students' families supported their achievement and many family members modeled success as professionals and academics. These family connections ensure a strong future orientation among the students.

In their examination of 20 years of national data, Wyner, Bridgeland, and Dilulio (2007) found high-ability students from higher-income families rapidly surpass their peers with similar abilities who have fewer economic resources. The privilege embedded in the academic experiences of the EP students (Jennings, Deming, Jencks, Lopuch, \& Schueler, 2015) is evident in the juxtaposition of narratives with their SC peers. The unruly academic environments and inadequate resources described by SC students contrast starkly with complaints of slow computers or delayed online grading. Income allows for the acquisition of resources. In any comparison of high- and low-income groups, we would expect to see a difference in the resources available for their academic achievement, as we did among these students.

The reward structure for EP students included access to academic competitions, advanced classes and special programs. Their environments were not ideal, however, and they spent much of their time not learning when they desperately wanted to be learning. In many cases, teachers neglected their needs for differentiated instruction. Their attention to other, less advanced students may have been warranted, but were perhaps consequential. For example, when the teacher did not call on students raising their hands (EPG3, 7/17/14), she or he may have been trying to give other students an opportunity to respond, but an unintended consequence may have been inappropriate competence feedback to the high-ability student. The 
structure of teachers' instruction is important to the development of competence and students' academic self-efficacy (Reeve, 2006).

EP students faced difficulties in the social arena. While an egocentric focus on their own achievement retards the development of interpersonal relationships with classmates and teachers, such a focus may be a response to a lack of appreciation from others. EP students often experienced peers and even teachers as impediments, not as friends or supporters. French, Walker, and Shore (2011) found that, when the gifted students in their sample felt appreciated by teachers and peers, they were less likely to prefer working alone. Gifted students in gifted classrooms had better relationships with their teachers than those in heterogeneous classes (Vogl \& Preckel, 2014). More research is needed to better understand how the classroom or school environment may be contributing to this negative social dynamic.

Students in the low-income, SC group also described numerous strengths, primarily in the form of supportive people in their lives. Friends, teachers, and other school officials contributed to students' strong sense of connectedness in their school communities. Similar to the lowincome, gifted African American students in VanTassel-Baska et al.'s (2009) study, SC students received praise for their academic abilities and had confidence in themselves. VanTassel-Baska et al. (1994) found high levels of social competence among the African American gifted students in their study, consistent with our findings among SC students. These strengths were important in navigating their academic environments, which were sometimes chaotic and restive. The social integration of the students potentially functioned as a protective element against some of the negative goings-on for some students, particularly when the academic gestalt was tumultuous. SC students were challenged by a variety of environmental barriers. Peers who were disengaged from academics served as powerful distractions to SC students, enticing these high- 
ability students to follow their non-academic lead. Schools rewarded students' academic success with activities that diverted them from further achievement. Although SC students may have reveled in extra playtime, it was a pernicious prize. While they enjoyed a play day for their achievement, their EP peers were getting a further boost in their academic development with competitions and enriching opportunities, which will have a much more positive effect on their ultimate achievement (Galster, Marcotte, Mandell, Wolman, \& Augustine, 2007; Horn \& Kojaku, 2001). Although these rewards might have been fun and were intended to reward achievement, they may have communicated an anti-intellectual message to the students, further damaging their academic progress.

According to this analysis, both groups are not likely to be learning to their potential. They were frequently bored and suffered from an anti-intellectual climate. Their classrooms could have been better structured for optimal learning. Emotional connectedness, a necessary component of a psychologically supportive environment, abounded among the SC students, a situation that might be reversed if they were in homogeneous gifted classes. Their EP peers, however, described very poor relationships with others in their schools, with girls most affected. Vogl and Preckel's (2014) findings of better fit for students in gifted classes may be culturally specific and not appropriate for students like those in the SC, the majority of whom were African American.

The balance among autonomy, competence, and relatedness needs is critical to individual well-being (Deci \& Ryan, 2000). Competence and autonomy must go hand in hand with a drive for relationships and a sense of belonging and community. It is therefore critical that the development of talent in youth address relatedness needs as well as the need to feel competent and autonomous. 


\section{Poverty of a Different Kind}

Perhaps most surprising in our findings was the poverty of the EP students' peer and teacher relationships. Their relationships with peers appear to exist on a dark spectrum, from benignly neglectful on one end to antagonistic and painful on the other. The EP girls seemed to be in particular distress. There is ample literature regarding the differentness these students feel (Cross, Coleman, \& Terhaar-Yonkers, 1991; Manor-Bullock, Look, \& Dixon, 1995) and there is evidence that gifted students sometimes hide their abilities to avoid being negatively perceived (Coleman \& Cross, 1988; Coleman, Micko, \& Cross, 2016). The intense negativity of the EP students' relationships with their peers suggests a harsh reality that demands further study.

The negativity of the EP students' relationships with teachers was surprising, as well, but, perhaps, confirming of research on teacher attitudes toward gifted students. Cramond and Martin (1987) found that studious, non-athletic adolescents were the least favored student profiles in a sample of teachers. Geake and Gross (2008) found that teachers had negative attitudes toward gifted students, particularly in the social realm. Fortunately, they also found these attitudes were improved through professional development.

The enormity of the mayhem and the disruption it caused to the education of the SC students was another striking finding. Some high-ability SC students were exposed to situations and general chaos that would make learning nearly impossible; a poverty of educational experience. The loss of potential from lost instruction time, alone, is sure to be substantial. Although we expected to find different barriers to achievement in these two groups of middleschool children, we were taken aback by the magnitude of the mayhem the SC students described and the degree of EP students' social disconnection.

\section{Supporting Interpersonal Connections: Engagement for All}


Deci and Ryan (2000) contend that relatedness needs are not necessarily contradictory with the need for autonomy, but can be placed in conflict when one feels a sense of connection is dependent on submission to the control of others. Bullying and the lack of regard for peers highlight how autonomy and relatedness needs are being placed at odds in the classroom for the EP students. Despite their substantial resources, these students could potentially lose motivation for academic pursuits to fulfill their need for social connection. Numerous studies have found that gifted students attempt to hide their achievement from peers (e.g., Cross, Coleman, \& Terhaar-Yonkers, 1991; Cross, O’Reilly, Kim, Mammadov, \& Cross, 2015; Swiatek, 2012), suggesting that many high-ability students may be underachieving to fit in socially. Students with gifts and talents are not inherently anti-social or summarily rejected by peers, but environments can exacerbate poor social fit (Cross, 2015; Cross, Bugaj, \& Mammadov, 2016). A strong connection to people not educationally inclined could potentially lead students to downplay and eventually walk away from educational pursuits. Hamm (2000) found evidence for such a course of action in her longitudinal study of peer relationships. The African American students in her study were more likely to choose friends who were similar in ethnic identity than in academic orientation. There is ample evidence that peers influence academic achievement (e.g., Altermatt \& Pomerantz, 2005; Berndt \& Keefe, 1995; Shin \& Ryan, 2014). If high-ability students choose friends with a less enthusiastic academic orientation, it is possible they will lose interest in academics. The school community via its teachers, other engaged educational leaders and public recognition of academic achievement, is actively competing for the affections of students in the low-income group, encouraging them in their pursuit of academics. These factors might serve as important protectors (Brody, Dorsey, Forehand, \& Armistead, 2002; McNair \& 
Johnson, 2009), but there is the risk that this pursuit will break down for some over time, as their connection to friends who do not prize education takes on greater importance to them.

We argue that an effective means of encouraging academic achievement will be to support the classmates of these high-ability students. Engaging high-ability students and their peers in interesting, relevant, and challenging curricula, will give students common ground on which to build relationships centered around academics. Enabling all students to build an identity that includes a future requiring academic preparation supports their modeling for one another how to be a good student (Frazier, 2012; Oyserman, Brickman, Bybee, \& Celious, 2006). An emphasis on classmates' engagement can also affect chaotic environments in the low-income schools. Boredom is a negative emotion associated with a lack of control and/or valuing of the activity (Pekrun, Hall, Goetz, \& Perry, 2014). It can be avoided by giving students control over activities they find valuable. When all students are given opportunities to engage in meaningful work that is relevant to them and their futures, they are less likely to cause disruptions for their peers. A focus on talent development for all students has the potential to lift all boats, including those carrying highly able youth (Frazier, Cross, \& Cross, 2015; Renzulli, 1998).

Another benefit of this academic reorganization for the SC students is that it might help these highly able students better understand the resources to which they do not have access. Low-income youth are more apt to be school-dependent. Ladson-Billings (2008) noted that school-dependent students look to schools to provide pathways to social mobility. Griffin, Allen, Kimura-Walsh, and Yamamura (2007) demonstrated that, when students are aware of the resource deficits in their academic environments, they can problem solve together to address shortfalls. This is especially relevant, considering too many low-income, high-ability students 
remain unable to access gifted services, due to barriers ranging from identification protocols to district budgets.

Many of the EP students were doubly handicapped. Like their SC peers, they were unsatisfied in their autonomy and competence needs, but they also suffered from poor relationships with their peers. Over time, some of these students are likely to sacrifice academics to pursue relationships (Gross, 1989). Or, they might maintain academic motivation, but become increasingly psychologically unbalanced in their alienation, leading to ill-being (Ryan \& Deci, 2000). Relatedness needs for well-being may be met by familial as well as school-based relationships. A classroom could be an unfulfilling place, but a loving family sets floor functioning, allowing a child to find other avenues for prospering (Deci \& Ryan, 2000; McNair \& Johnson, 2009). School-related solutions to this dilemma exist, as well. Schools need not be a place these high-ability students avoid or detest because of the poor peer relations that happen there. Research linking benefits of competition to outstanding performance (Worrell et al., 2016) gives scant attention to the effect on interpersonal relationships of environments built around the competition to outperform peers (Exline, Single, Lobel, \& Geyer, 2004; Massé \& Gagné, 2002). Research has found cooperative learning to be effective in reducing prejudice (Slavin, 2001). Thoughtfully constructed cooperative activities that require interdependence of all members, allowing each to work at her or his ability level (Huss, 2006), can help students fulfill their needs for autonomy, competence, and relatedness.

\section{Limitations}

Qualitative research, by design, does not lead to universal claims. Likewise, the use of focus group interviews precludes any assumption that salient issues define every interview participant. Thus, for example, although many SC students experienced some degree of mayhem 
in their learning environments, this was not a feature for all students in the program. Similarly, not all EP students reported experiences of isolation. We believe, however, that we have uncovered a range of student observations explaining what constitutes barriers for this sample. The breadth of our findings was made possible through the use of focus group interviews, which are an effective and economical means of gathering subjects together and allowing them to express their views in a group format (Bloor et al., 2001). The length of interviews is a potential limitation, however. Ideally, they would have been longer. Although there may be concerns that individual voices of some students who spoke less frequently may not have been equally represented in the interviews, the interviewers made a point of ensuring all or nearly all participants were an active part of the conversation.

It would have been beneficial to include individual interviews with students. One place of analysis would have been the degree of overlap between individual interviews and focus group interviews. The use of 14 focus group interviews from students of different perspectives about the same phenomenon partially addresses this concern, as the conversations appeared to the researchers quite robust, rich, and varied, with all or most students actively engaging in each interview. This was also a significantly higher number of interviews than required to reach thematic saturation (Namey et al., 2016).

As in most research involving convenience samples, our findings may not be representative of the population in its entirety. All students in the sample attended special programs, but we do not know the specific schooling contexts of the individual participants. Not all high-ability students in the low-income schools may have levels of social support similar to the SC students. Similarly, the high-ability, high-income peers of EP students may have more favorable relationships with peers and teachers. The evidence is compelling, however, that we 
have captured the experience of these students in our findings. Although the students attended programs in slightly different settings, steps were taken to ensure the interview process was as equivalent as possible. For example, the time to build rapport was extended in EP interviews so the students would feel as comfortable speaking together as did their SC peers. Despite these limitations, this study's findings make a useful springboard for future research.

\section{Conclusion}

Schools can promote the interconnectedness of students by truly celebrating diversity (including cognitive diversity), going beyond superficial claims of tolerance, and by encouraging respect and prosocial behaviors at all levels, including among teachers, staff, and administrators. When all students are offered the opportunity to master rigorous curriculum with relevant and interesting subject matter, competition can be with the self and previous performance rather than with peers. Respect for students requires a meaningful and appropriately paced curriculum for all students in an environment that is adequately resourced. Only by leveling the playing field in academic opportunities will a closure of the income-based achievement gap be seen. It is necessary for schools to offer more resources to students in low-income environments for them to achieve to their potential. Fairness is not achieved by an equal distribution of funding, as some legislators have proposed (e.g., Brody, 2016), when communities have dramatically differing resources, such as those described by SC and EP students. When poorly maintained or equipped schools receive the same funding as adequately maintained and equipped schools, the disparity between them is never reduced. To make real progress in closing the achievement gap between high- and low-income students, such as the SC and EP students who participated in this study, solutions must include equitable funding. 


\section{References}

Alfeld-Liro, C., Fredricks, J. A., Hruda, L. Z., Patrick, H., Ryan, A. M., \& Eccles, J. (1998, February). Nurturing teenagers' talent: The role of parents, teachers, and coaches. Paper presented at the meeting of the Society for Research on Adolescence, San Diego, CA.

Altermatt, E. R., \& Pomerantz, E. M. (2005). The implications of having high-achieving versus low-achieving friends: A longitudinal analysis. Social Development, 14, 61-81. https://doi.org/10.1111/j.1467-9507.2005.00291.x

Anfara, V.A., Brown, K.M., \& Mangione, T.L. (2002). Qualitative analysis on stage: Making the research process more public. Educational Researcher, 31(7), 28-38. https://doi.org/10.3102/0013189X031007028

Bandura, A. (1997). Self-efficacy: The exercise of control. New York, NY: Freeman.

Berndt, T. J., \& Keefe, K. (1995). Friends' influence on adolescents' adjustment to school. Child Development, 66, 1312-1329. https://doi.org/10.2307/1131649

Bloor, M., Frankland, J., Thomas, M., \& Robson, K. (2001). Focus groups in social research. London, UK: Sage. https://doi.org/10.4135/9781849209175

Bogdan, R. C., \& Biklen, S. K. (2007). Qualitative research for education: An introduction to theory and methods (5th ed.). Boston, MA: Allyn \& Bacon.

Brody, G.H., Dorsey, S., Forehand, R., \& Armistead, L. (2002). Unique and protective contributions of parenting and classroom processes to the adjustment of African American children living in single-parent families. Child Development, 73(1), 274-286. https://doi.org/10.1111/1467-8624.00405

Brody, L. (2016, June 21). Christie announces new school-funding plan. Wall Street Journal. Retrieved from http://www.wsj.com/articles/christie-announces-new-school-funding- 
plan- 1466552933

Bronfenbrenner, U. (1979). The ecology of human development. Cambridge, MA: Harvard Press.

Burney, V. H., \& Beilke, J. R. (2008). The constraints of poverty on high achievement. Journal for the Education of the Gifted, 31, 295-321. https://doi.org/10.4219/jeg-2008-771

Chapman, C., Laird, J., Ifill, N., \& KewalRamani, A. (2011). Trends in high school dropout and completion rates in the United States: 1972-2009 (NCES 2012-006). Washington, DC:

National Center for Education Statistics, Institute of Education Sciences, U.S. Department of Education.

Cooper, S., \& Endacott, R. (2007). Generic qualitative research: A design for qualitative research in emergency care? Emergency Medicine Journal, 24, 816-819. https://doi.org/10.1136/emj.2007.050641

Creswell, J. W. (2013). Qualitative inquiry \& research design: Choosing among five approaches. Los Angeles, CA: Sage.

Cross, J. R. (2015). Peer relationships of gifted children. In M. Neihart, S. Pfeiffer, \& T. L. Cross (Eds.). Social and emotional development of gifted children, $2^{\text {nd }}$ ed. (pp. 41-54). Washington, DC: National Association for Gifted Children.

Cross, J. R., Bugaj, S. J., \& Mammadov, S. (2016). Accepting a scholarly identity: Gifted students, academic crowd membership, and identification with school. Journal for the Education of the Gifted, 39, 23-48. https://doi.org/10.1177/0162353215624162

Cross, J. R., O’Reilly, C., Kim, M., Mammadov, S. \& Cross, T. L. (2015). Social coping and self-concept among young gifted students in Ireland and the United States: A crosscultural study. High Ability Studies, 26, 39-61.

https://doi.org/10.1080/13598139.2015.1031881 
Cross, T. L., Coleman, L. J., \& Terhaar-Yonkers, M. (1991). The social cognition of gifted adolescents in schools: Managing the stigma of giftedness. Journal for the Education of the Gifted, 15, 44-55. https://doi.org/10.1177/016235329101500106

Cyr, J. (2016). The pitfalls and promise of focus groups as a data collection method. Sociological Methods \& Research, 45, 231-259. https://doi.org/10.1177/0049124115570065

Deci, E. L., \& Ryan, R. M. (2000). The what and why of goal pursuits: Human needs and the self-determination of behavior. Psychological Inquiry, 1, 227-268. https://doi.org/10.1207/S15327965PLI1104_01

Eccles, J. S. (2004). Schools, academic motivation, and stage-environment fit. Handbook of adolescent psychology, 2, 125-153. https://doi.org/10.1002/9780471726746.ch5

Eccles, J.S., \& Midgley, C. (1989). Stage-environment fit: Developmentally appropriate classrooms for young adolescents. In C. Ames \& R. Ames (Eds.), Research on Motivation in Education (Vol. 3; pp. 139-186). San Diego, CA: Academic Press.

Eccles, J.S., Midgley, C., Wigfield, A., Buchanan, C.M., Reuman, D., Flanagan, C., \& Mac Iver, D. (1993). The impact of stage-environment fit on young adolescents' experiences in schools and in families. American Psychologist, 48 (2), 90-101. https://doi.org/10.1037/0003-066X.48.2.90

Eccles, J.S., \& Roeser, R.W. (1999). School and community influences on human development. In M.H. Bornstein \& M. E. Lamb (Eds.), Developmental psychology: An advanced textbook ( $4^{\text {th }}$ ed.; pp. 503-554). Mahwah, NJ: Lawrence Erlbaum.

Eccles, J. S., \& Roeser, R. W. (2009). Schools, academic motivation, and stage-environment fit. In R. M. Lerner \& L. Steinberg (Eds.), Handbook of adolescent psychology ( ${ }^{\text {rd }}$ ed.; pp. 404-434). Hoboken, NJ: John Wiley \& Sons. 
https://doi.org/10.1002/9780470479193.adlpsy001013

Exline, J. J., Single, P. B., Lobel, M., \& Geyer, A. L. (2004). Glowing praise and the envious gaze: Social dilemmas surrounding the public recognition of achievement. Basic and Applied Social Psychology, 26, 119-130.

https://doi.org/10.1080/01973533.2004.9646400

Frazier, A. D. (2012). The possible selves of high-ability African males attending a residential high school for highly able youth. Journal for the Education of the Gifted, 35(4), 366390. https://doi.org/10.1177/0162353212461565

Frazier, A. D., Cross, J. R., \& Cross, T. L. (2015). Talent development as career development and college readiness in gifted African American youth. In J. R. Curry \& M. A. Shillingford (Eds.), African American students' career and college readiness (pp. 85108). Lanham, MD: Lexington Books.

French, L. R., Walker, C. L., \& Shore, B. M. (2011). Do gifted students really prefer to work alone? Roeper Review, 33, 145-159. https://doi.org/10.1080/02783193.2011.580497

Galster, G., Marcotte, D.E., Mandell, M., Wolman, H., \& Augustine, N. (2007). The influence of neighborhood poverty during childhood on fertility, education, and earnings outcomes. Housing Studies, 22, 723-751. https://doi.org/10.1080/02673030701474669

Garn, A. C., Matthews, M. S., \& Jolly. J. L. (2010). Parental influences on the academic motivation of gifted students: A self-determination theory perspective. Gifted Child Quarterly, 54(4), 263-272. https://doi.org/10.1177/0016986210377657

Griffin, K. (2006). Striving for success: A qualitative exploration of competing theories of highachieving black college students' academic motivation. Journal of College Student Development, 47(4), 384-400. https://doi.org/10.1353/csd.2006.0045 
Griffin, K. A., Allen, W. R., Kimura-Walsh, E., Yamamura, E. K. (2007). Those who left, those who stayed: Exploring the educational opportunities of high-achieving Black and Latina/o students at magnet and nonmagnet Los Angeles high schools (2001-2002). Educational Studies, 42, 229-247. https://doi.org/10.1080/00131940701632662

Gross, M. U. M. (1989). The pursuit of excellence or the search for intimacy? The forced-choice dilemma of gifted youth. Roeper Review, 11, 189-194. https://doi.org/10.1080/02783198909553207

Hamm, J. V. (2000). Do birds of a feather flock together? The variable bases for African American, Asian American, and European American adolescents' selection of similar friends. Developmental Psychology, 36, 209-219. https://doi.org/10.1037/00121649.36.2.209

Hoekman, K., McCormick, J., \& Gross, M. U. M. (1999). The optimal context for gifted students: A preliminary exploration of motivational and affective considerations. Gifted Child Quarterly, 43(4), 170-193. https://doi.org/10.1177/001698629904300304

Horn, L., \& Kojaku, L. (2001). High school academic curriculum and the persistence path through college (NCES 2001-163). Retrieved from http://nces.ed.gov/pubs2001/2001163.pdf

Huss, J. A. (2006). Gifted education and cooperative learning: A miss or a match? Gifted Child Today, 29 (4), 19-23. https://doi.org/10.4219/gct-2006-13

Jennings. J.L., Deming, D., Jencks, C., Lopuch, M., \& Schueler, B.E. (2015). Do differences in school quality matter more than we thought? New evidence on educational opportunity in the twenty-first century. Sociology of Education, 88(1), 56-82. https://doi.org/10.1177/0038040714562006 
Kahlke, R.M. (2014). Generic qualitative approaches: Pitfalls and benefits of methodological mixology. International Journal of Qualitative Methods, 13, 37-52. https://doi.org/10.1177/160940691401300119

Knodel, J. (1993). The design and analysis of focus group studies: A practical approach. In D.L. Morgan (Ed), Successful focus groups: Advancing the state of the art (pp. 35-50). Newbury Park, CA: Sage. https://doi.org/10.4135/9781483349008.n3

Ladson-Billings, G. (2008). "Yes, but how do we do it?" Practicing culturally relevant pedagogy. In W. Ayers \& P. Ford (Eds.), City kids, city schools: More reports from the front row (pp.162-177). New York, NY: New Press.

Manor-Bullock, R., Look, C., \& Dixon, D. N. (1995). Is giftedness socially stigmatizing? The impact of high achievement on social interactions. Journal for the Education of the Gifted, 18, 319-338. https://doi.org/10.1177/016235329501800307

Marshall, C., \& Rossman, G. B. (2006). Designing qualitative research (4 ${ }^{\text {th }} \mathrm{ed}$.). Thousand Oaks, CA: Sage.

Massé, L., \& Gagné, F. (2002). Gifts and talents as sources of envy in high school settings. Gifted Child Quarterly, 46, 15-29. https://doi.org/10.1177/001698620204600103

Maxwell, J.A. (2013). Qualitative research: An interactive approach. Thousand Oaks, CA: Sage.

McNair, R., \& Johnson, H.D. (2009). Perceived school and home characteristics as predictors of school importance and academic performance in a diverse adolescent sample. North American Journal of Psychology, 11(1), 63-84. 
Merriam, S. B., \& Tisdell, E. J. (2015). Qualitative research: A guide to design and implementation (4th ed.). San Francisco: Jossey-Bass. https://doi.org/10.4018/978-14666-7409-7.ch007

Morgan, D.L. (1997). Focus groups as qualitative research: Qualitative research methods series (Vol. 16, $2^{\text {nd }}$ ed.). Thousand Oaks, CA: Sage. https://doi.org/10.4135/9781412984287

Morgan, M., Gibbs, S., Maxwell, K., \& Britten, N. (2002). Hearing children's voices: Methodological issues in conducting focus groups with children aged 7-11. Qualitative Research, 2, 5-20. https://doi.org/10.1177/1468794102002001636

Namey, E., Guest, G., McKenna, K., \& Chen, M. (2016). Evaluating bang for the buck: A costeffectiveness comparison between individual interviews and focus groups based on thematic saturation levels. American Journal of Evaluation, 37, 425-440. https://doi.org/10.1177/1098214016630406

Oyserman, D., Brickman, D., Bybee, D., \& Celious, A. (2006). Fitting in matters: Markers of ingroup belonging and academic outcomes. Psychological Science, 17, 854-861. https://doi.org/10.1111/j.1467-9280.2006.01794.x

Patton, M. Q. (1999). Enhancing the quality and credibility of qualitative analysis. Health Services Research, 34, 1189-1208.

Pekrun, R., Hall, N. C., Goetz, T., \& Perry, R. P. (2014). Boredom and academic achievement: Testing a model of reciprocal causation. Journal of Educational Psychology, 106, 696710. https://doi.org/10.1037/a0036006 
Percy, W.H., Kostere, K., \& Kostere, S. (2015). Generic qualitative research in psychology. The Qualitative Report, 20 (2), 76-85. Retrieved from http://www.nova.edu/ssss/QR/QR20/2/percy5.pdf

Punch, S. (2002). Interviewing strategies with young people: The 'Secret Box', stimulus material and task-based activities. Children \& Society, 16, 45-56. https://doi.org/10.1002/chi.685

Reardon, S.F. (2011). The widening academic achievement gap between the rich and the poor: New evidence and possible explanations. In R. Murnane \& G. Duncan (Eds.), Whither Opportunity? Rising Inequality and the Uncertain Life Chances of Low-Income Children (pp. 91-116). New York, NY: Russell Sage Foundation Press.

Reeve, J. (2006). Teachers as facilitators: What autonomy-supportive teachers do and why their students benefit. The Elementary School Journal, 106, 225-236. https://doi.org/10.1086/501484

Renzulli, J. S. (1998). A rising tide lifts all ships: Developing the gifts and talents of all students. Phi Delta Kappan. 80, 104-111.

Renzulli, J. S., \& Park. S. (2000). Gifted dropouts: The who and the why. Gifted Child Quarterly, 44(4), 261-271. https://doi.org/10.1177/001698620004400407

Rodriguez, K.L., Schwartz, J.L., Lahman, M.K.E., \& Geist, M.R. (2011). Culturally responsive focus groups: Reframing the research experience to focus on participants. International Journal of Qualitative Research, 10(4), 400-417. https://doi.org/10.1177/160940691101000407

Ryan, R. M., \& Deci, E. L. (2000). Self-determination theory and the facilitation of intrinsic motivation, social development, and well-being. American Psychologist, 5, 68-78. https://doi.org/10.1037/0003-066X.55.1.68 
Ryan, R. M., \& Deci, E. L. (2002). Overview of self-determination theory: An organismic dialectical perspective. In E. L. Deci \& R. M. Ryan (Eds.) Handbook on selfdetermination research (pp. 4-33). Rochester, NY: The University of Rochester Press.

Schunk, D. H., \& Pajares, F. (2005). Competence perceptions and academic functioning. In A. J. Elliott \& C. S. Dweck (Eds.), Handbook of competence and motivation (pp. 85-105). New York, NY: Guilford Press.

Shin, H., \& Ryan, A. M. (2014). Early adolescent friendships and academic adjustment: Examining selection and influence processes with longitudinal social network analysis. Developmental Psychology, 50, 2462-2472. https://doi.org/10.1037/a0037922

Slavin, R. E. (2001). Cooperative learning and intergroup relations. In J. A. Banks \& C. M. M. Banks (Eds.), Handbook of research on multicultural education (pp. 628-634). San Francisco: Jossey-Bass.

Swanson, J. (2010). The patterns and profiles of gifted low-income Caucasian children. In J. L. VanTassel-Baska (Ed.) Patterns and profiles of promising learners from poverty (pp. 129-156). Waco, TX: Prufrock Press.

Swiatek, M. A. (2012). Social coping. In T. L. Cross \& J. R. Cross (Eds.), Handbook for counselors serving students with gifts and talents (pp. 665-679). Waco, TX: Prufrock Press.

VanTassel-Baska, J., Feng, A. X., Swanson, J. D., Quek, C., \& Chandler, K. (2009). Academic and affective profiles of low-income, minority, and twice-exceptional gifted learners: The role of gifted program membership in enhancing self. Journal of Advanced Academics, 20, 709-739. https://doi.org/10.1177/1932202X0902000406

VanTassel-Baska, J., Olszewski-Kubilius, P., \& Kulieke, M. (1994). A study of self-concept and 
social support in advantaged and disadvantaged seventh and eighth grade gifted students. Roeper Review, 16, 186-191. https://doi.org/10.1080/02783199409553570

Vogl, K., \& Preckel, F. (2014). Full-time ability grouping of gifted students: Impacts on social self-concept and school-related attitudes. Gifted Child Quarterly, 58, 51-68. https://doi.org/10.1177/0016986213513795

Wang, M., \& Eccles, J. S. (2013). School context, achievement motivation, and academic engagement: A longitudinal study of school engagement using a multidimensional perspective. Learning and Instruction, 28, 12-23. https://doi.org/10.1016/j.learninstruc.2013.04.002

Whiting, G. W., \& Ford, D. Y. (2009). Black students and Advanced Placement classes: Summary, concerns, and recommendations. Gifted Child Today, 32, 23-26. https://doi.org/10.4219/gct-2009-840

Worrell, F. C., Knotek, S. E., Plucker, J. A., Portenga, S., Simonton, D. K., Olszewski-Kubilius, P., Schultz, S. R., \& Subotnik, R. F. (2016, July 25). Competition's role in developing psychological strength and outstanding performance. Review of General Psychology. Advance online publication. https://doi.org/10.1037/gpr0000079

Wyner, J. S., Bridgeland, J. M., \& Dilulio, J. J., Jr. (2007). Achievement trap: How America is failing millions of high-achieving students from lower-income families. Retrieved from http://www.jkcf.org/assets/files/0000/0084/Achievement_Trap.pdf

Zabloski, J., \& Milacci, F. (2012). Gifted dropouts: Phenomenological case studies of rural gifted students. Journal of Ethnographic \& Qualitative Research, 6, 175-190. 
Table 1

Constraining Environments Theme Sample Excerpts

\begin{tabular}{|c|c|c|}
\hline & Low-Income Summer Camp & High-Income Enrichment Program \\
\hline $\begin{array}{l}\text { Constraining } \\
\text { Environments: } \\
\text { Stagnant } \\
\text { Academic } \\
\text { Conditions }\end{array}$ & $\begin{array}{l}\text { S1: In class after I finish my work, everybody isn't finished-I be } \\
\text { the first one to finish cuz it's so easy and I start talking; I be } \\
\text { getting in trouble and I be so bored! I be so bored! I be like } \\
\text { "Uuuuhhh, can I leave?" I be goin' to other classes, see what they } \\
\text { doing. (SCG3, 7/25/12) }\end{array}$ & $\begin{array}{l}\text { S: Especially in math and science, it's like I'm at a higher level than } \\
\text { even the [advanced] classes, so it's like review, week after week after } \\
\text { week and I'm never learning. (EPB2, 7/18/13) }\end{array}$ \\
\hline $\begin{array}{l}\text { Constraining } \\
\text { Environments: } \\
\text { Inhibiting } \\
\text { Peers }\end{array}$ & $\begin{array}{l}\text { S: Sometimes in class when the kids are talking and you can't } \\
\text { really understand what the teacher is saying. And then they give } \\
\text { you homework on what they taught in class and you don't really } \\
\text { know it because everybody was talking. } \\
\text { (SCB1, 7/25/12) }\end{array}$ & $\begin{array}{l}\text { S: Some of these girls, they just like hated me because all the teachers } \\
\text { liked me, 'cuz I was the only one who listened. She had actually went } \\
\text { and took her nails and dug in my arm. And it's just like - "What did I } \\
\text { do to you? I'm sitting here trying to learn." And this year, it's more } \\
\text { they freeload off of you, so they're like, "I'm kind of behind. I don't } \\
\text { know why, I just can't keep up." Stop talking! So, they'll try to, like, } \\
\text { copy my homework, so I have to hide all of my work, like lay on top } \\
\text { of it or hide it in my bookbag. (EPG1, 3/16/13) }\end{array}$ \\
\hline $\begin{array}{l}\text { Constraining } \\
\text { Environments: } \\
\text { Teachers } \\
\text { Contribute to } \\
\text { Poor Fit }\end{array}$ & $\begin{array}{l}\text { S: I had this teacher, she only likes girls and she hates boys. } \\
\text { S2: That's what they be doing at my school, they be treating girls } \\
\text { better because like, they let the girls go to the bathroom anytime } \\
\text { they want and then we ask they tell us to sit down and wait until } \\
\text { the class ends. It's like } 2 \text { hours in that class. We're not supposed to } \\
\text { be talking and the boys be talking. We be getting into serious } \\
\text { trouble, when the girls be talking they just let them talk. (SCB3, } \\
\text { 7/25/12) }\end{array}$ & $\begin{array}{l}\text { S: One of my teachers from last year, well...I have two teachers that } \\
\text { were weird; one of them-well not - one of them wasn't weird, but } \\
\text { one of them, she was the weird one, she's a science teacher and she } \\
\text { does not know any science. (EPG3, 7/17/14) }\end{array}$ \\
\hline $\begin{array}{l}\text { Constraining } \\
\text { Environments: } \\
\text { Mayhem in } \\
\text { Students' } \\
\text { Environment }\end{array}$ & $\begin{array}{l}\text { S: In our school they have policemen on every corridor and } \\
\text { security guards and like, they're a little too sensitive, though. You } \\
\text { make one move and they're up against you, telling you to get } \\
\text { against the wall, pointing their tazer at you, 'cuz they is like too } \\
\text { strict. If you slam your locker or something-you know how you } \\
\text { can slam your locker, not even meaning to? And then you'll turn } \\
\text { around and see somebody like "Yaaay!" you know, you all about } \\
\text { to hug. They see something like that, they misinterpret it and } \\
\text { they'll put you up against the wall. } \\
\text { (SCG3, 7/25/12) }\end{array}$ & $\begin{array}{l}\text { S: Well, sometimes in my school, like when we were trying to like go } \\
\text { to another class, there would be some arguments. And sometimes } \\
\text { those people get late for class and then the teacher, like when we're } \\
\text { trying to learn something, those people come in but he takes that time } \\
\text { to like, fuss at them and then it will take away our learning time. } \\
\text { (EPG1, 3/16/13) }\end{array}$ \\
\hline
\end{tabular}




\begin{tabular}{|l|l|l|}
\hline $\begin{array}{l}\text { Constraining } \\
\text { Environments: } \\
\text { Mayhem in } \\
\begin{array}{l}\text { Students' } \\
\text { Environment }\end{array}\end{array}$ & $\begin{array}{l}\text { S: Because the teacher always has to leave the classroom to see } \\
\text { what's going on and stop it and break it up. It happens a lot and } \\
\text { sometimes you are walking in the hallway and everyone starts } \\
\text { yelling, "Fight!" } \\
\text { (SCBG4, 7/25/12) }\end{array}$ & $\begin{array}{l}\text { S1: At my school, we do have security guards and they are armed with } \\
\text { weapons. } \\
\text { I: Is that something that you are aware of? What do you think about } \\
\text { that? } \\
\text { S1: Well, lots of times, they come in to talk to classes and stuff. I think } \\
\text { most people kind of ignore them. (EPB2, 7/18/13) }\end{array}$ \\
\hline
\end{tabular}

Note: I - Interviewer, S - Student, SCG - Low-Income Girls, SCB - Low-Income Boys, EPG - High-Income Girls, EPB - High-Income Boys

Table 2

Integration versus Isolation Theme Sample Excerpts

\begin{tabular}{|c|c|c|}
\hline & Low-Income Summer Camp & High-Income Enrichment Program \\
\hline $\begin{array}{l}\text { Integration } \\
\text { versus } \\
\text { Isolation }\end{array}$ & $\begin{array}{l}\text { S: I'd be so far ahead, so I'd just ask my English teacher, "Can I } \\
\text { go to Miss Smith's* class?" and she'd be like "Ok," so she'd give } \\
\text { me encouragement and stuff. (SCG3, 7/25/12) } \\
\text { *pseudonym }\end{array}$ & $\begin{array}{l}\text { S: I find a big connection between the kids that give you trouble and } \\
\text { bully you and cause distractions are often times the kids that are } \\
\text { asking you for help or what's the answer to this question and then } \\
\text { don't do well on the quiz. (EPG2, 7/17/13) }\end{array}$ \\
\hline $\begin{array}{l}\text { Integration } \\
\text { versus } \\
\text { Isolation }\end{array}$ & $\begin{array}{l}\text { S: Oh, yeah...our principal... best principal around the world. She } \\
\text { knows almost every student's name. } \\
\text { I: So does it help your learning when you feel like the principal } \\
\text { knows your name? } \\
\text { S: Yes. It makes you feel like they actually care about your } \\
\text { learning. (SCB1, 7/25/12) }\end{array}$ & $\begin{array}{l}\text { S: I have four different blocks and each block obviously, each class, I } \\
\text { have around } 20-30 \text { people and it is ridiculous, I can't even begin to tell } \\
\text { you how much hindrance there is with people. The teacher will tell us } \\
\text { to work with someone. Last thing I want to do, because the person } \\
\text { either does nothing and gets my good grade for my work or they wreck } \\
\text { it. }\end{array}$ \\
\hline \multicolumn{3}{|c|}{$\begin{array}{l}\text { Note: I - Interviewer, S - Student, SCG - Low-Income Girls, SCB - Low-Income Boys, EPG - High-Income Girls, EPB - High-Income Boys } \\
\text { Table } 3 \\
\text { Resource Plenty versus Resource Poor Theme Sample Excerpts }\end{array}$} \\
\hline & Low-Income Summer Camp & High-Income Enrichment Program \\
\hline $\begin{array}{l}\text { Resource } \\
\text { Plenty versus } \\
\text { Resource } \\
\text { Poor }\end{array}$ & $\begin{array}{l}\text { I: So how do y'all get on the Internet if you don't have it at } \\
\text { home? } \\
\text { S1: I have to wait for when my mom goes to her work and she } \\
\text { looks stuff up for me. } \\
\text { S2: I go to the library, too. } \\
\text { S3: Me and my friends go to the library or my aunt's house or } \\
\text { try to find some Wi-Fi. Wi-Fi don't work sometimes, so I go to }\end{array}$ & $\begin{array}{l}\text { S: Like at our school we get taught Latin and I get the highest grade in the } \\
\text { class every time and so me and two kids in my class are going to take the } \\
\text { National Latin Exam. (EPB1, 3/9/13) }\end{array}$ \\
\hline
\end{tabular}




\begin{tabular}{|c|c|c|}
\hline & 2) & \\
\hline $\begin{array}{l}\text { Resource } \\
\text { Plenty versus } \\
\text { Resource } \\
\text { Poor }\end{array}$ & $\begin{array}{l}\text { I: Who helps you be successful, helps you focus, helps you stay } \\
\text { focused? } \\
\text { S1: My mommy. } \\
\text { S2: My dad. } \\
\text { S3: My mom. } \\
\text { S4: All my teachers, pretty much. } \\
\text { S2: Mommy. } \\
\text { S4: The new 5th grade teacher at my school. She was my } \\
\text { substitute teacher a long time ago. } \\
\text { S5: My mommy. } \\
\text { S6: My cousin that's in } 8 \text { th grade, my neighbor who lives next } \\
\text { to me-she's like a mom to me, but she's only 13. (SCG3, } \\
\text { 7/25/12) }\end{array}$ & $\begin{array}{l}\text { I: [Who makes] it possible for you to become a successful student? } \\
\text { S1: My parents. } \\
\text { S2: My Dad. } \\
\text { S4: My Mom and Dad. } \\
\text { S1: My Dad. } \\
\text { S5: My parents, my laptop, my phone right next to me in case I need } \\
\text { some writing advice. Those three usually make for a good study session. } \\
\text { S6: For me, it's mainly my parents, 'cause they're the ones who are } \\
\text { feeding you, they are the ones who are making sure you're alive. They're } \\
\text { the ones who are giving you-putting you into camps for - for the better } \\
\text { of your future, and they're the ones, you know, who are giving you all } \\
\text { this...stuff that you want. (EPG4, 7/10/14) }\end{array}$ \\
\hline
\end{tabular}

Note: I - Interviewer, S - Student, SCG - Low-Income Girls, SCB - Low-Income Boys, EPG - High-Income Girls, EPB - High-Income Boys 
Table 4

Findings Shared and Differentiated by Group

\begin{tabular}{|c|c|c|}
\hline Low-Income Only & Both & High-Income Only \\
\hline \multicolumn{3}{|c|}{ Constraining Environments (Autonomy, Competence) } \\
\hline \multicolumn{3}{|c|}{ Boredom } \\
\hline \multicolumn{3}{|c|}{ Inadequate teachers } \\
\hline & No differentiated instruction & 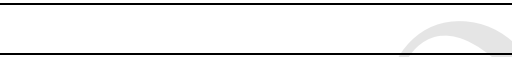 \\
\hline \multicolumn{3}{|c|}{$\begin{array}{c}\text { Classroom management } \\
\text { problems }\end{array}$} \\
\hline \multicolumn{3}{|c|}{ Peer distraction } \\
\hline \multicolumn{3}{|c|}{ 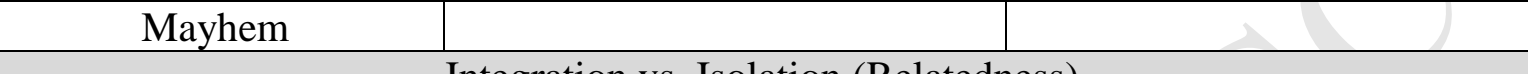 } \\
\hline \multicolumn{3}{|c|}{ Integration vs. Isolation (Relatedness) } \\
\hline Peer acceptance & & Peer rejection \\
\hline Supportive teachers & & Rejection of teachers \\
\hline \multicolumn{3}{|l|}{$\begin{array}{l}\text { Supportive school and } \\
\text { community members }\end{array}$} \\
\hline & Supportive family members & Y \\
\hline \multicolumn{3}{|c|}{ Resource Plenty vs. Resource Poor (Competence, Relatedness) } \\
\hline $\begin{array}{l}\text { Inadequate learning } \\
\text { resources }\end{array}$ & & $\begin{array}{c}\text { Adequate learning resources } \\
\text { (e.g., computers, advanced } \\
\text { classes) }\end{array}$ \\
\hline \multirow[t]{7}{*}{$\begin{array}{c}\text { Rewards for } \\
\text { achievement of playtime }\end{array}$} & & $\begin{array}{c}\text { Rewards for achievement of } \\
\text { academic opportunities }\end{array}$ \\
\hline & Confidence in academic ability & \\
\hline & Persistence & \\
\hline & Valuing of academics & \\
\hline & Family support for academics & \\
\hline & & $\begin{array}{l}\text { Family support for costly } \\
\text { achievement opportunities }\end{array}$ \\
\hline & & $\begin{array}{c}\text { Professional, highly educated } \\
\text { family members and } \\
\text { connections }\end{array}$ \\
\hline
\end{tabular}


Appendix

\section{Interview Protocol}

Thank you for agreeing to be a part of our research project. We are trying to learn about the lives of young kids, the goals they have and the kinds of things that make it hard for them to achieve those goals. We're going to start by watching this video about a boy even younger than you who did something pretty amazing. Watch http://cainesarcade.com.

What did you think? Did Caine have a goal? How did he achieve it?

Did he have personal characteristics that helped him accomplish his goals? What were they?

Were there things around him - things in his environment that made it possible to make his arcade?

What about people around him? Could he have done it without other people? Who? (His dad, filmmaker)

Was his goal realistic? He didn't make an arcade like one you see at Chuck E. Cheese, did he? Could he have done that? What would it take?

Do you know other people who have set goals for themselves and made them happen? Tell us about that.

Let's talk about academic goals. What would be an example of an academic goal? (Being a good student)

Have you ever had one?

Are there things about you that make it possible for you to be a successful student?

Are there things in your environment that make it possible?

Are there people who help you?

What about things about you (characteristics) or your environment (resources) or people around you who keep you from achieving your academic goal? Are there examples of that?

(Note: Follow-up questions will ask about inhibiting events, people, resources, behaviors, and opportunities.)

Example Follow-up Questions

1. Are there things that happen in your school that can keep you from achieving?

2. How do/does [topic mentioned; e.g., sports, friends, teacher] get in the way of your learning? 